\title{
Simulation of the Hydrodynamic Functioning of the Cavally River Using a Coupled 1D-2D Model in the Ity Area (Zouan-Hounien in Côte d'Ivoire)
}

\author{
Affoué Berthe Yao*, Kouao Armand Anoh, Loukou Alexis Brou, Menouan Wilfried Goli, \\ Lazare Kouakou Kouassi \\ Laboratory of Environmental Sciences and Technologies, UFR Environment, University Jean Lorougnon Guédé, Daloa, \\ Côte d'Ivoire \\ Email: *y_berth@yahoo.fr
}

How to cite this paper: Yao, A.B., Anoh, K.A., Brou, L.A., Goli, M.W. and Kouassi, L.K. (2021) Simulation of the Hydrodynamic Functioning of the Cavally River Using a Coupled 1D-2D Model in the Ity Area (Zouan-Hounien in Côte d'Ivoire). Open Journal of Modern Hydrology, 11, 75-84. https://doi.org/10.4236/ojmh.2021.114005

Received: August 29, 2021

Accepted: October 27, 2021

Published: October 30, 2021

Copyright $\odot 2021$ by author(s) and Scientific Research Publishing Inc. This work is licensed under the Creative Commons Attribution International License (CC BY 4.0).

http://creativecommons.org/licenses/by/4.0/

(c) (i) Open Access

\begin{abstract}
In recent years, the Cavally River has been subject to multiple activities, including the construction of diversion channels and a bridge that makes it vulnerable to flooding. In order to assess the impact of these hydraulic structures on the river hydrodynamic functioning, a $1 \mathrm{D}-2 \mathrm{D}$ model was realized. The implementation of the $1 \mathrm{D}-2 \mathrm{D}$ model consisted of first running the $1 \mathrm{D}$ model, then the 2D model, and finally in coupling them. The 1D-2D model was designed with the 1988 flood hydrograph, a Manning's coefficient of $0.052 \mathrm{~m}^{1 / 3} / \mathrm{s}$ for the minor bed and $0.06 \mathrm{~m}^{1 / 3} / \mathrm{s}$ for the major bed. The results of the hydraulic model show that the velocities are almost identical to those of the Cavally in natural operation. The values of the velocities are included between $0.4 \mathrm{~m} / \mathrm{s}$ and 1.3 $\mathrm{m} / \mathrm{s}$ at the level of the minor bed of the river and between $0.06 \mathrm{~m} / \mathrm{s}$ and 0.71 $\mathrm{m} / \mathrm{s}$ at the level of the floodplains. The average water level for flood propagation is $262.37 \pm 0.44 \mathrm{~m}$ before construction of the structures and $262.23 \pm 0.85$ $\mathrm{m}$ after construction of the structures. The $0.41 \mathrm{~m}$ reduction in water level due to the diversion canal and bridge is negligible compared to the total fluctuations of the Cavally River, which vary from 6 to $7 \mathrm{~m}$ over the year.
\end{abstract}

\section{Keywords}

Ity Mines, 1D-2D Modeling, Flooding, Cavally River, Côte d'Ivoire

\section{Introduction}

Water is a very important resource for the development of life on the Earth planet. Indeed, the development of almost all socio-economic activities depends on its availability. Unfortunately, its vital nature means that it is under strong pres- 
sure in many places on the planet [1], particularly in Sub-Saharan Africa where it is becoming increasingly scarce [2]. In Côte d'Ivoire, the combination of anthropogenic activities and the deterioration of climatic factors affect water resources both quantitatively and qualitatively. [3] [4] [5] have shown that the increase in population and economic activities near rivers has increased the risk of flooding in many watersheds. The Cavally watershed, particularly in the locality of ZouanHounien does not spare this observation. Indeed, according to [6], the Cavally watershed is subject to all kinds of anthropogenic activities. Among these activities, agriculture, livestock and, industrial and artisanal mining contribute strongly to the modification of the river hydrological functioning. The Ity Mining Company (SMI), which relies on this resource for its mining activities, plans to cut several meanders of the river to build diversion canals at these places. Yet, the impact of hydraulic developments on the river hydrodynamic functioning has been shown by [7]. The latter highlighted the extent of flood wave propagation and probable flood zones near the perimeter of Ity Mining Company (SMI). Thus, given the recurrence of floods and the importance of the river both for SMI and the local population, it is necessary to better understand the hydrological functioning of the Cavally River in the locality of Zouan-Hounien. Therefore, the objective of this study is to evaluate the impact of hydraulic structures on the hydrodynamic functioning of Cavally River. To achieve this objective, coupled 1D/2D modeling remains the first approach tool to understand the hydrodynamic behavior of the river in the minor and major beds.

\section{Material and Methods}

\subsection{Description of Study Area}

Located in the west part of Côte d'Ivoire, Cavally River originates from the lower transboundary hydrographic basin, located between Côte d'Ivoire and Liberia. Cavally River has its source in Guinea, north of Nimba Mountain, at an altitude of around $600 \mathrm{~m}$ [8]. The total area drained by the Cavally watershed is 28,800 $\mathrm{km}^{2}$ of which $15,000 \mathrm{~km}^{2}$ is located in Ivorian territory [9]. As part of this study, the basin was delimited with the Floleu hydrometric station as its outlet (Figure 1). The Floleu hydrometric station is located downstream of Ity station which is administratively located in the Zouan-Hounien region. Zouan-Hounien region is located in the mountain region having a climate characterized by two seasons: a rainy season from May to October and a dry season from November to March. The average annual temperature is $25.6^{\circ} \mathrm{C}$ while the average annual rainfall is 1,866 $\mathrm{mm}$. The pedology is dominated by ferralitic type soils with average chemical fertility and hydromorphic soils [10]. The vegetation is characterized by a dense forest with important tree species. The most important of which are Iroko (Chlorophora excels), Bete (Mansonia altissima), Samba (Triplochiton scleroxylon), Framire (Terminali ivorensis), Mahogany of Grand Bassam Khaya (Ivorensis), Miangon (Heritiera utilis), Tiama (Entandrophragma Angolense) and Cheese Tree (Terminalia ivorensis) [11]. 


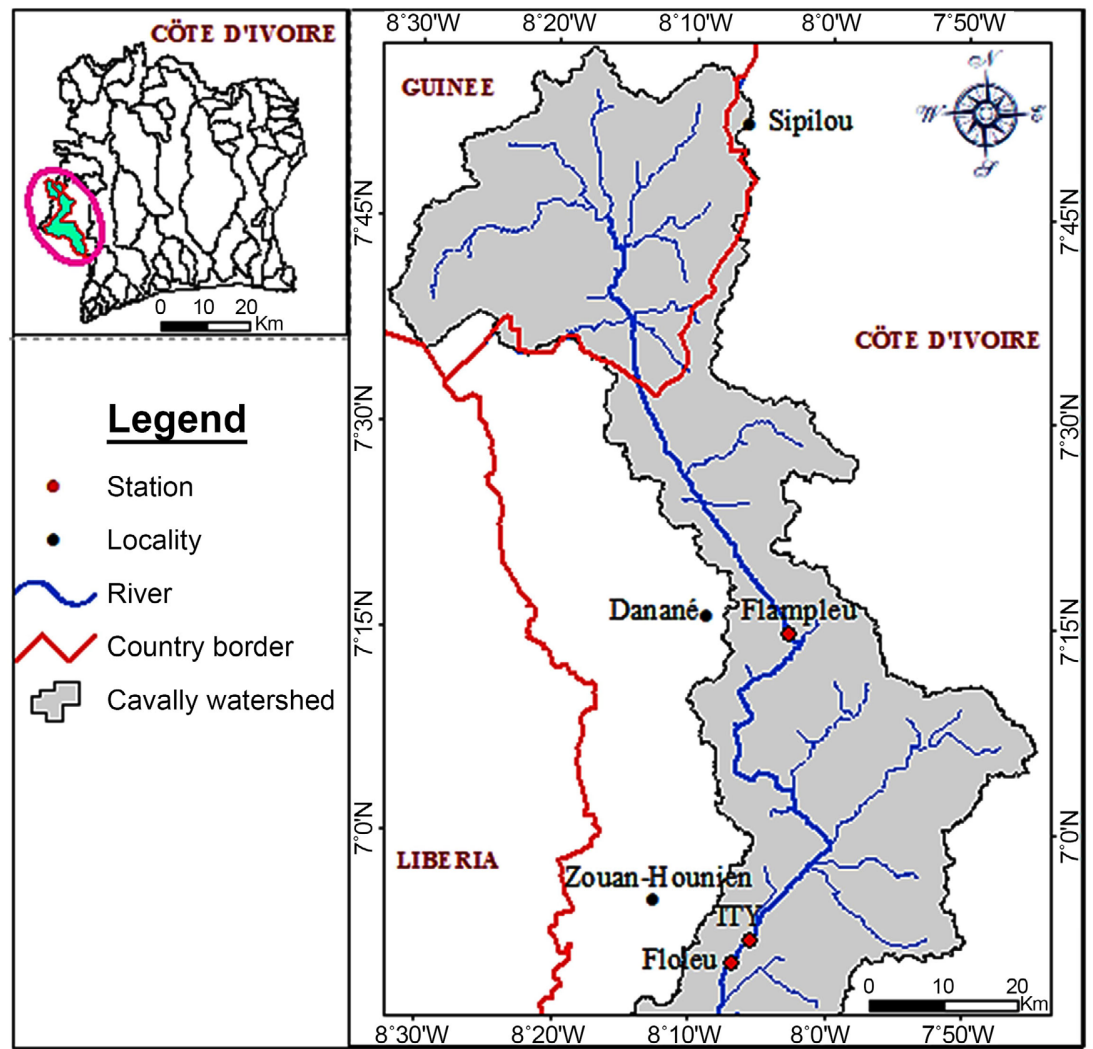

Figure 1. Study area.

\subsection{Data and Material Used}

Two types of data (point and raster) were useful for the study. The point data are exclusively related to the streamflow. Historical data of flows on a daily time step over the period 1980-2001 were provided by the Hydrology Direction (DH) of Côte d'Ivoire. To corroborate these data, several measurement campaigns were carried out on a section of the Cavally River between Bakatouo and Floleu-Soklaleu from 2015 to 2019. These measurement campaigns concerned the measurements of the streamflow, current speeds, water levels, bathymetric surveys and the collection of sediment samples. Note that these measurements were carried out during high water periods (July and October) and low water periods (February and March) by [10]. The raster data concerns Ligth Detection and Ranging (LIDAR) images with a resolution of $0.50 \mathrm{~m}$. The tools necessary for data processing are softwares. Thus, the software HEC-RAS 5.04 (for modeling the hydrodynamic functioning of Cavally River) and Arcgis 10.0 (for producing flood propagation maps) were of great use or the realization of this study.

\subsection{Methods}

The methodology implemented is divided into three main steps. It first consisted in setting up a 1D model, then a 2D model [7], finally to couple the 1D model to the $2 \mathrm{D}$ model. An evaluation of the model performance will allow judging the quality of the outputs. 


\subsubsection{Modeling of Free Surface Flows in 1D}

In order to include the hydraulic structures, the modeling of the hydraulic structures influence was carried out using the 1D model of HEC-RAS. The structures concerned are the diversion canal and the bridge of Daapleu, the diversion canals of Bakatouo. HEC-RAS is a model that is widely used in the field of free surface hydraulics. It uses the 1D Saint-Venant equations to relate the water heights, flows and velocities. These equations are deduced from the Navier-Stokes equations through simplifications related to the stream morphology [12]. The equations involved in 1D modeling are the conservation of mass equation (Equation (1)) and the conservation of momentum equation (Equation (2)).

$$
\begin{gathered}
\frac{\partial A_{T}}{\partial t}+\frac{\partial Q}{\partial x}-q_{i}=0 \\
\frac{\partial Q}{\partial t}+\frac{\partial Q V}{\partial x}+g A\left(\frac{\partial z}{\partial x}+S_{f}\right)=0
\end{gathered}
$$

with: $A_{T}$ : wetted section $\left(\mathrm{m}^{2}\right) ; Q$ : flow $\left(\mathrm{m}^{3} / \mathrm{s}\right) ; q_{i}$ : linear flow; $t$ t time $(\mathrm{s}) ; x$ : longitudinal distance $(\mathrm{m}) ; z$. water level elevation; $S_{f}$ representative friction angle between two sections. $\frac{\partial z}{\partial x}$ : Slope of the channel bottom.

The solution of the 1D model equations is based on the finite difference theory. The simulation was carried out over a period of 3 months. The boundary conditions of the model are:

- Upstream: the flood hydrograph of the year 1988. The choice of this period is justified by the consistency of the data and the most important flood recorded in the watershed;

- Downstream: a longitudinal slope of $1.94 \times 10^{-4} \mathrm{~m} / \mathrm{m}$ was imposed as a boundary condition.

\subsubsection{Modeling of Free Surface Flows in 2D}

The $2 \mathrm{D}$ flood propagation modeling allows better appreciation of the spatial distribution of the flood. It shows the flood extent (free water surface), the distribution of streamlines (the velocity) and the distribution of flood depth. The conservation (Equation (3)) and momentum (Equation (4) and Equation (5)) equations are written as follows:

$$
\begin{gathered}
\frac{\partial}{\partial x}(h u)+\frac{\partial}{\partial y}(h v)+\frac{\partial}{\partial t} H+q=0 \\
\frac{\partial u}{\partial t}+u \frac{\partial u}{\partial x}+v \frac{\partial u}{\partial y}=-g \frac{\partial H}{\partial x}+v_{i}\left(\frac{\partial^{2} u}{\partial x^{2}}+\frac{\partial^{2} u}{\partial y^{2}}\right)-c_{f} u+f v \\
\frac{\partial u}{\partial t}+u \frac{\partial v}{\partial x}+v \frac{\partial v}{\partial y}=-g \frac{\partial H}{\partial y}+v_{i}\left(\frac{\partial^{2} v}{\partial x^{2}}+\frac{\partial^{2} v}{\partial y^{2}}\right)-c_{f} v+f u
\end{gathered}
$$

where: $t$ is time; $u$ and $v$ are the velocities in the Cartesian $x$ and $y$ directions; $q$ is the elementary flow; $H$ is the free water surface elevation; $g$ is the gravitational acceleration, $v_{t}$ is the horizontal vortex viscosity coefficient, $c_{f}$ is the bottom friction coefficient, and $f$ is the Coriolis parameter. The initial conditions applied to 
the $2 \mathrm{D}$ model are identical to the initial conditions of the $1 \mathrm{D}$ model. Return periods of 10, 20, 50 and 100 years were used to perform the different simulations.

\subsubsection{Modeling of Free Surface Flows in 1D-2D}

The $1 \mathrm{D}-2 \mathrm{D}$ coupling is a modeling that combines hydraulic structures and flood propagation in the calculations. The mesh used for the 1D-2D modeling covers the portion of the Cavally River from the Ity station to the Floleu station. The size of the square meshes was set to $30 \mathrm{~m} \times 30 \mathrm{~m}$. The lateral structure that serves as a connection between 1D model and 2D model has been changed so that the elevation of the lateral structure does not exceed the mesh elevation of the $2 \mathrm{D}$ zone mesh.

\subsubsection{Evaluation of Model Performance}

The performance of the model was evaluated according to two criteria which are statistics and graphics. The statistical criteria concern the Nash Coefficient (NS) [13] and the Root Mean Square Error (RMSE) [14]. The visual criteria consist in appreciating the similarity between the observed and calculated water line curve. Note that for a good performance of the model, the Nash coefficient must be very close to 1 for a strong link between the observed and simulated values. To give an order of magnitude, values exceeding 0.65 are considered acceptable and 0.75 satisfactory [15]. Its expression is given by Equation (6).

$$
\mathrm{NS}=1-\frac{\sum_{i=1}\left(Q_{m}-\bar{Q}_{s}\right)^{2}}{\sum_{i=1}\left(Q_{m}-\bar{Q}_{m}\right)^{2}}
$$

with $Q_{m}$ : observed flow, $Q_{s}$ : simulated flow, $\bar{Q}_{m}$ : average of measured flows and $\bar{Q}_{s}$ : average of simulated flows.

Along with NS criteria value, RMSE value close to zero indicates a satisfactory performance of the model. Its expression is given by Equation (7).

$$
\text { RMSE }=\sqrt{\frac{1}{n} \sum_{i=1}^{n}\left(y_{i}-\bar{y}_{i}\right)^{2}}
$$

where: $n$ is the total number of observations; $y_{i}$ is an observed value and $\bar{y}_{i}$ is a respective simulated value.

Waterline data from July 2015 were used for model calibration while data measured in 2019 were used for model validation.

\section{Results and Discussion}

\subsection{Results}

Figure 2 and Figure 3 show respectively the results of calibration and validation after water line variation. The analysis of the observed and simulated water lines shows a good synchronization. This good similarity between the observed and simulated values is moreover highlighted by the statistical criteria that are the Nash coefficient ( 0.87 for calibration and 0.83 for validation) and the RMSE coefficient ( 0.081 for calibration and 0.065 for validation). 


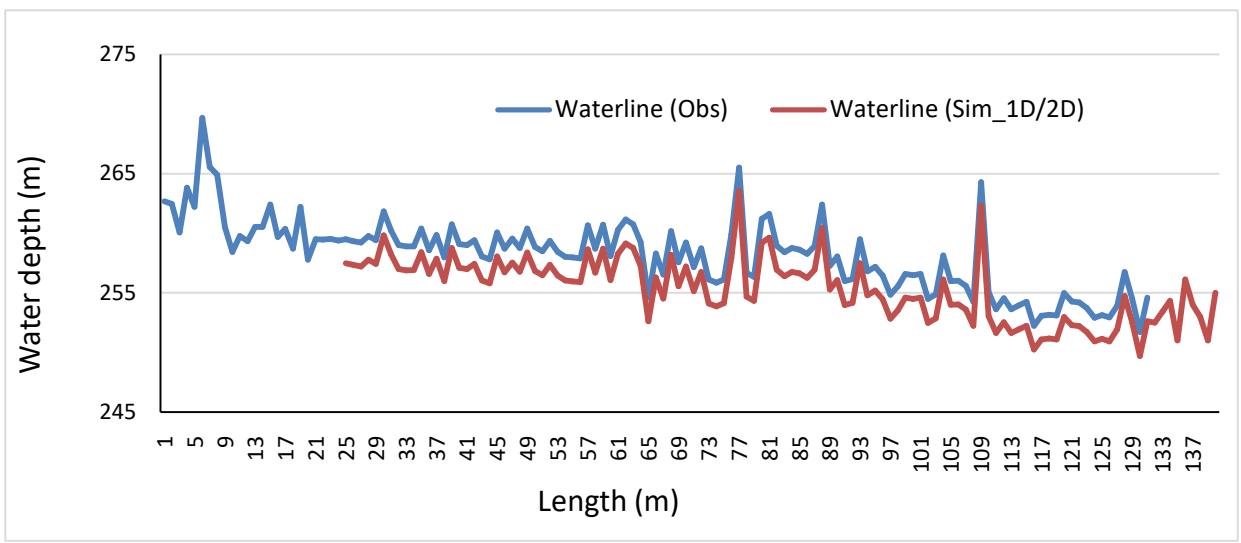

Figure 2. Simulated and observed water line for the calibration period.

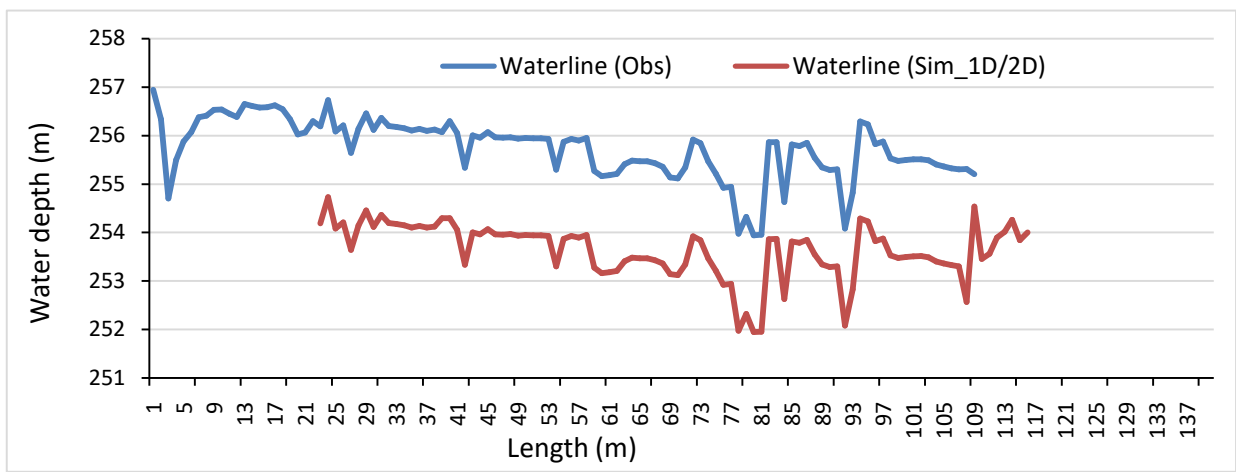

Figure 3. Simulated and observed water line for the validation period.

The velocities before and after the realization of the hydraulics structures are relatively weak at the level of the banks and high in the minor bed. Before the cutting of meanders, the value of the maximum velocities in the minor bed of river is $1.04 \mathrm{~m} / \mathrm{s}$ (Figure $4(\mathrm{a})$ ). After the cutting of meanders (Figure 4(b)), the maximum velocities of propagation in the minor bed of river are of the order of $1.3 \mathrm{~m} / \mathrm{s}$. So the values of velocities are included between $1.04 \mathrm{~m} / \mathrm{s}$ and $1.3 \mathrm{~m} / \mathrm{s}$ at the level of the minor bed of the watercourse, and between $0.06 \mathrm{~m} / \mathrm{s}$ and $0.71 \mathrm{~m} / \mathrm{s}$ at the floodplains level. The highest velocities are observed in the meander cut zone. In addition, under natural conditions, we note an acceleration of the velocities at the entrance of the meanders. In terms of flood propagation, an average water level of $262.37 \pm 0.44 \mathrm{~m}$ was observed before the construction of the hydraulics structures. After the construction of these structures, the average water level is $262.23 \pm 0.85 \mathrm{~m}$.

The difference in water level over the entire floodplain is almost negligible compared to the annual fluctuation of the Cavally River water level. The greatest depths obtained in the flood propagation model are observed upstream of the portion of the river studied, specifically at the periphery of the SMI Company. Figure 5(a) and Figure 5(b) show the flood propagation zones of the Cavally River before and after the construction of the hydraulic structures for the 1988 flood. 

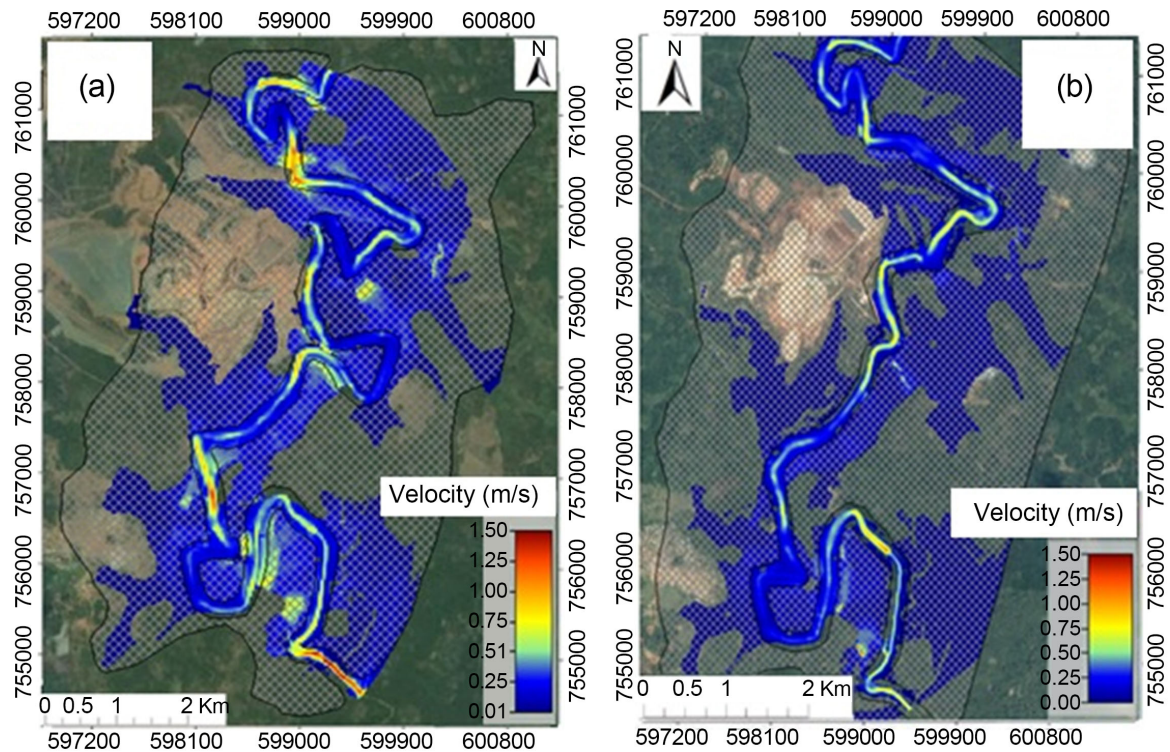

Figure 4. Distribution of velocities in the stream bed before (a) and after (b) diversion of the Cavally.
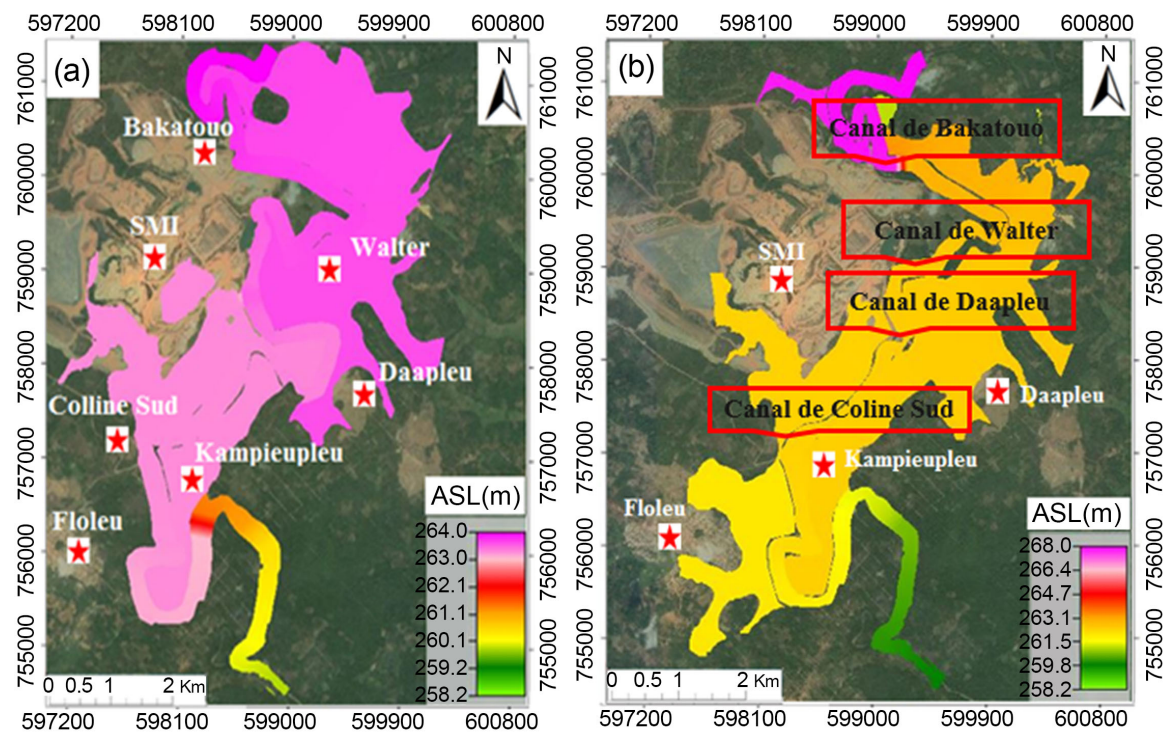

Figure 5. Extent of free water surface altitudes (ASL) of the Cavally River floods before (a) and after (b) construction of the structures.

\subsection{Discussion}

The study conducted to simulate the hydrodynamic functioning of the Cavally River using a coupled 1D-2D model required to evaluate the performance of the model. So, the evaluation of the performance of HEC-RAS was statistically analyzed using the two statistical criteria of model efficiency (Nash coefficient). The results of the calibration and validation indicate a very good performance of the model with a NS $=0.87$ for the calibration and NS $=0.83$ for the validation. Regarding the RMSE, its values are also 0.081 for the calibration and 0.065 for the validation. These values are in agreement with the recommendations by [13] 
[14] [15]. So, the velocities are approximately the same on the portion of the stream studied. On the other hand, a difference of some meters is observed in the depth and free surface (ASL) of the water. The velocities before and after the diversion channel are relatively low on the banks and high in the minor bed. Similar results have been reported by several authors including [7] [16] [17]. These authors concluded in their work that the installation or construction of a hydraulic structure on a stream should not cause a significant disturbance of the hydrodynamic parameters of that stream. The comparison of water levels before and after the diversion of the river for the 1988 flood showed that the Cavally River will not really be disturbed by the hydraulic structures [10]. Indeed the 0.41 $\mathrm{m}$ reduction in water level due to the diversion channel is negligible compared to the total fluctuations of the Cavally River, which vary from 6 to $7 \mathrm{~m}$ in the year. Moreover, according to [18] [19] [20], this decrease in water level fluctuations reduces flooding phenomena. Therefore, it appears that the hydraulic conditions of the stream, would not be significantly different from the existing natural conditions upstream and downstream of the diversion channel.

\section{Conclusion}

The work presented in this article focuses on the realization of a hydraulic model to assess the hydrodynamic function of the Cavally River after the realization of a diversion channel on the portion of the river close to the SMI Company. The implementation of the 1D-2D model gave very good performance with statistical criteria close to 1 for NS and 0 for RMSE. Thus, the flow velocities vary from 0.5 $\mathrm{m} / \mathrm{s}$ to $1.3 \mathrm{~m} / \mathrm{s}$ after the integration of the structures. In terms of flood propagation, an average water level of $262.37 \pm 0.44 \mathrm{~m}$ and $262.23 \pm 0.85 \mathrm{~m}$ were respectively observed before and after the construction of these structures. The hydraulic structures do not have a considerable impact on the hydrodynamic functioning of Cavally, because the hydraulic conditions (water levels, flow and velocity) in the whole river bed are not strongly modified compared to the initial state of the Cavally.

\section{Acknowledgements}

The authors would like to thank the Ity Company (SMI) for providing funds and data for this study.

\section{Conflicts of Interest}

The authors declare no conflicts of interest regarding the publication of this paper.

\section{References}

[1] Loudière, D. and Gourbesville, P. (2020) Rapport mondial des Nations Unies sur la mise en valeur des ressources en eau 2020: L'eau et les changements climatiques. $\mathrm{La}$ Houille Blanche, 106, 76-81. https://doi.org/10.1051/lhb/2020024

[2] Baron, C. (2010) L'eau en Afrique: disponibilité et accès. Futuribles, Paris, 33-55. 
https://doi.org/10.1051/futur/35933

[3] Brou, Y.T., Akindès, F. and Bigot, S. (2005) La variabilité climatique en Côte d'Ivoire: Entre perceptions sociales et réponses agricoles. Cahiers Agricultures, 14, 533-540.

[4] Nadège, B.K.A.N., Cissé, G., Koné, B. and Séri, D. (2016) Variabilite climatique et changements dans l'environnement a Korhogo en Cote d'Ivoire: Mythes ou realite? European Scientific Journal, 12, 158. https://doi.org/10.19044/esj.2016.v12n5p158

[5] Chen, W.-B. and Liu, W.-C. (2017) Modeling the Influence of River Cross-Section Data on a River Stage Using a Two-Dimensional/Three-Dimensional Hydrodynamic Model. Water, 9, 203. https://doi.org/10.3390/w9030203

[6] Séraphin, K.K., Lazare, K.K., Félix, K.K., Sylvestre, Y.A. and Alexis, B.L. (2020) Impacts de l'orpaillage sur la morphologie et la qualité des eaux du fleuve Cavally (Zouan-hounien, Côte d'Ivoire). International Journal of Innovation and Applied Studies, 28, 515-524.

http://www.issr-journals.org/links/papers.php?journal=ijias\&application=pdf\&artic le=IJIAS-19-306-01

[7] Lazare, K.K., Alexis, B.L., Berthe, Y.A., Alex, K.Z., Séraphin, K.K., Félix, K.K. and Bérenger, K. (2019) 1D-2D Hydraulic Modeling of a Diversion Channel on the Cavally River in Zouan-Hounien, Cote d'Ivoire. Journal of Water Resource and Protection, 11, 1036. https://doi.org/10.4236/jwarp.2019.118061

[8] Girard, G. and Sircoulon, J. (1968) Aperçu sur les régimes hydrologiques de Côte d'Ivoire. 1-61.

[9] Tricart, J. (1973) Une monographie physique de la Côte-d'Ivoire. Annales de Géographie, 82, 369-372.

[10] Brou, L.A. (2019) Modélisation de la Dynamique Hydrologique du Fleuve Cavally sous l'Influence de fortes Pressions Anthropiques dans la Zone de Zouan-Hounien (Côte d'Ivoire). Ph.D. Thesis, Université Jean Lorougnon Guédé, Côte d'Ivoire.

[11] Ettien, D. (2010) Exploitation industrielle des gisements d'or et dynamique spatiale du terroir d'Ity dans l'Ouest de la Côte d'Ivoire, Une étude à base de la télédétection. Revue de Géographie du Laboratoire Leïdi, 8, 1-15.

[12] Hec, O. and Hec-Ras, H. (2013) Concepts de base de la modelisation hydrologique et hydraulique. https://pdf.usaid.gov/pdf docs/PA00K1HG.pdf

[13] McCuen, R.H., Knight, Z. and Cutter, A.G. (2006) Evaluation of the Nash-Sutcliffe Efficiency Index. Journal of Hydrologic Engineering, 11, 597-602. https://doi.org/10.1061/(ASCE)1084-0699(2006)11:6(597)

[14] Chai, T. and Draxler, R.R. (2014) Root Mean Square Error (RMSE) or Mean Absolute Error (MAE)?-Arguments against Avoiding RMSE in the Literature. Geoscientific Model Development, 7, 1247-1250. https://doi.org/10.5194/gmd-7-1247-2014

[15] Anoh, K.A., Konan, K.S., Eblin, S.G., Atcho, A.V. and Kouassi, K.L. (2021) Contribution of Agro-Hydrological Modeling in the Evaluation of Water Availability of an Ungauged Basin Reservoir in Côte d'Ivoire: Case of the Loka Reservoir in Bouaké. Computational Water, Energy, and Environmental Engineering, 10, 117-130. https://doi.org/10.4236/cweee.2021.103009

[16] Kane, S., Sambou, S., Leye, I., Diedhiou, R., Tamba, S., Cisse, M.T., Ndione, D.M. and Sane, M.L. (2017) Modeling of Unsteady Flow through Junction in Rectangular Channels: Impact of Model Junction in the Downstream Channel Hydrograph. Computational Water, Energy, and Environmental Engineering, 6, 304-319. https://doi.org/10.4236/cweee.2017.63020 
[17] Göktaş, R.K., Ayvaz, M.T., Kargı, P.G., Erdoğan, E.K., Mesta, B., Tezyapar, İ. and Tezel, U. (2018) Effect of Land Surface Elevation Data Availability on River Hydraulic Model Output. European Geosciences Union General Assembly, 20, EGU201814885 .

[18] Mah, D.Y.S., Lai, S.H., Chan, R.A.R.B. and Putuhena, F.J. (2012) Investigative Modelling of the Flood Bypass Channel in Kuching, Sarawak, by Assessing Its Impact on the Inundations of Kuching-Batu Kawa-Bau Expressway. Structure and Infrastructure Engineering, 8, 705-714. https://doi.org/10.1080/15732471003770167

[19] Kim, C. and Kang, J. (2013) Case Study: Hydraulic Model Study for Abandoned Channel Restoration. Engineering, 5, 989-996. https://doi.org/10.4236/eng.2013.512120

[20] Campisano, A., Cutore, P. and Modica, C. (2014) Improving the Evaluation of SlitCheck Dam Trapping Efficiency by Using a 1D Unsteady Flow Numerical Model. Journal of Hydraulic Engineering, 140, Article ID: 04014024.

https://doi.org/10.1061/(ASCE)HY.1943-7900.0000868 